\title{
COMPETITOR-FOCUSED ACCOUNTING: AN EXPLORATORY NOTE
}

There appears to be a burgeoning interest in competitor analysis amongst strategy commentators and management practitioners. ${ }^{1}$ This interest is typified by Porter's influential writings (1980, 1985) which suggest that competitor analysis is fundamental to the pursuit of competitive advantage. He argues that the importance of this analysis warrants companies maintaining “... an organized mechanism - some sort of competitor intelligence system - to insure that the process is efficient” (1980, p.72). There is currently the beginning of a management accounting literature on competitor-focused accounting (CFA). Despite this development, no study concerned with appraising CFA adoption rates or related contingent factors has been found in the literature. The exploratory study reported herein was conducted in light of this apparent gap in prior research. The study's objectives are:

a) to appraise CFA adoption rates;

b) to assess practitioners' perceptions of the extent to which CFA could be helpful to their organization; and

c) to develop and test propositions concerned with contingent factors that might affect CFA adoption rates as well as perceptions of CFA's helpfulness.

The paper is structured as follows. In the context of a review of what practices comprise CFA, the next section provides a synthesis of the most pertinent literature. This is followed by a section that develops a theoretical framework concerned with factors that might affect CFA adoption rates as well as perceptions of CFA's helpfulness. Subsequent sections address, in turn, the research method employed, the survey's results and a conclusion that discusses the study's findings as well as its limitations.

\section{WHAT PRACTICES COMPRISE COMPETITOR-FOCUSED ACCOUNTING?}

No attempt to synthesise CFA practices was found in the literature. For this reason, the development of a listing of CFA practices is bound to be exploratory. In an attempt to delimit this problem, significant emphasis has been attached to the way CFA practices have been described in the literature. Only those CFA practices described in a manner highlighting a distinction from other CFA practices are included. The following five CFA practices have been drawn from the literature and are now described in turn:

(i) competitor cost assessment

(ii) competitive position monitoring

(iii) competitor appraisal based on published financial statements

(iv) strategic costing

(v) strategic pricing.

Competitor cost assessment is probably the most widely-referred to CFA practice. Amongst its advocates are Bromwich (1990), Jones (1988), Porter (1985), Simmonds (1981) and Ward (1992). The significant attention commanded by competitor cost assessment may result partially from the growing sophistication in technologically-advanced investments. Jones (1988) provides a persuasive case that the long-term commitment associated with such investment and the implied pursuit of improved competitive position, heightens the need for awareness of competitors' costs. He outlines a systematic approach to competitor cost assessment that involves, inter alia, appraising competitors' manufacturing facilities, economies of scale, governmental relationships, and technology-product design. Further to these approaches, Ward (1992) describes "indirect sources" of competitor information which include: physical observation, mutual suppliers, mutual customers, and employees (particularly ex-employees of competitors). Competitor cost assessment is defined in this study as the provision of a regularly 
updated estimate of a competitor's unit cost.

Competitive position monitoring, as advocated by Simmonds (1986), represents a more holistic mode of CFA than competitor cost assessment. It broadens the analysis to include appraising major competitors' sales, market share, volume, unit costs and sales. Simmonds notes that an increase in a competitor's cost per unit may initially appear favourable. If this increase has resulted from advertising devoted to brand strength development or from investment in new product development, however, the changed cost structure may be more suggestive of the competitor securing a stronger rather than a weaker competitive position. Simmonds argues that extending management accounting's measures beyond their conventional internally-focused domain can strengthen appraisals of competitor strategy. Competitive position monitoring is defined in this study as the analysis of competitor positions within the industry by assessing and monitoring trends in competitor sales, market share, volume, unit costs, and return on sales. This information can provide a basis for the assessment of a competitor's strategy.

Moon and Bates (1993) describe an approach to competitor appraisal which is based on published financial statement interpretation. The specific nature of the approach to data collection evident in this mode of CFA has given rise to its separate consideration here. The significance of this specificity is underlined by the fact that, unlike the approaches already considered, published financial statement interpretation involves techniques that are familiar to traditionally-trained accountants. Moon and Bates outline an analytical framework that can be applied to a competitor's published statements as part of an appraisal of key sources of competitive advantage. This analysis can include monitoring trends in sales and profit levels as well as asset and liability movements. Moon and Bates claim that strategically significant insights can be derived from an appropriately conducted analysis of a competitor's published statements. ${ }^{2}$ Competitor appraisal based on published financial statements is defined in this study as the numerical analysis of a competitor's published statements as part of an assessment of a competitor's key sources of competitive advantage.

Strategic costing is a widely-used term in many of Shank and Govindarajan's (1988; 1991; 1992; 1993) publications. They believe that in order for cost analysis to support the pursuit of competitive advantage, it must explicitly consider strategic issues. Their 1988 study uses a case analysis to demonstrate the sub-optimal decision that can result from using a conventional costing approach (i.e., an analysis conducted from a "relevant" cost, short-run perspective). Employing an analysis that considers strategic issues and draws on concepts articulated in the marketing and competitive strategy literatures (e.g., product positioning and market penetration), Shank and Govindarajan show how a preferred solution to the case can be derived. Strategic costing is defined in this study as the use of cost data based on strategic and marketing information to develop and identify superior strategies that will produce a sustainable competitive advantage.

Strategic pricing is discussed in the context of case studies by Jones (1988) and Simmonds (1982). The more extensive consideration is provided by Simmonds who demonstrates how suboptimality can result from a pricing decision informed by a conventional accounting analysis based on internally-orientated, historically-based information. He claims that strategic pricing which uses competitively-orientated analysis will result in a better-informed pricing decision. Included in the factors that might be appraised in such an analysis are competitor price reaction, price elasticity, projected market growth, economies of scale and experience. Foster and Gupta's (1994) survey finding that accounting information's greatest potential use is perceived by marketing executives to be in connection with pricing decisions underlines the importance of separate consideration applied to this mode of CFA. Strategic pricing is defined in this study as 
the analysis of strategic factors in the pricing decision process. These factors may include: competitor price reaction, price elasticity, market growth, economies of scale, and experience.

\section{TOWARDS A CONTINGENCY THEORY OF COMPETITOR-FOCUSED ACCOUNTING}

Propositions concerning four contingent factors that might affect CFA adoption rates as well as perceptions of CFA's helpfulness are developed in this section. Following calls for research into the role strategy might play in accounting system design (Otley, 1980; Dent, 1990; Simons, 1990; Chapman, 1997; Langfield-Smith, 1997), and, more especially, the prima facie relevance of strategy to CFA, the implications of two strategy dimensions are considered. These two dimensions are strategic mission and competitive strategy. In addition, the potentially contingent roles played by company size and industry are explored.

Strategic mission. Strategic mission relates to the nature of the strategic goal pursued. One example of the operationalisation of strategic mission is Govindarajan and Gupta's (1985) "build/harvest" measure. This measure is designed to determine where a business lies on the spectrum ranging from pursuit of high market share (build) to the pursuit of short-term profit (harvest).

Porter (1980) believes that the desire to preempt competitors in deliberations on capacity expansion is one of the clearest examples of organizational decision making where competitor information can play an invaluable role. In a similar vein, Zajac and Bazerman (1991) see a need for competitor analysis when considering capacity expansion. These views suggest that "build" firms will have a greater call for competitor information.

Proposition 1a: CFA usage rates are higher in companies pursuing a build strategic mission than in companies pursuing a harvest strategic mission.

Proposition 1b: CFA's perceived helpfulness is greater in companies pursuing a build strategic mission than in companies pursuing a harvest strategic mission.

Competitive strategy. Competitive strategy relates to how business units compete. This dimension of strategy has been operationalised in prior accounting studies (Simons, 1987; Abernethy and Guthrie, 1994) using Snow and Hrebiniak's (1980) measure which is based on Miles and Snow's (1978) four strategic archetypes: "prospector”, “analyser”, “reactor” and "defender". Snow and Hrebiniak operationalised the "prospector" archetype using terms such as "values being 'first in' in new product and market areas", and "responds rapidly to early signals concerning areas of opportunity, and these responses often lead to a new round of competitive actions" (1980, p.336). At the other extreme, the "defender" archetype has more inwardlyfocused characteristics, i.e., "trying to protect its domain by offering higher quality, superior service, lower prices, and so forth", and "it tends to ignore industry changes.... and concentrates instead on doing the best job possible in a limited area" (p.336). These characterisations highlight contrasting internal/external foci, leading to the expectation that CFA will be more compatible with firms that exhibit a "prospector" (more externally-orientated) strategy. Further support for this expectation arises from Zajac and Bazerman's (1991) description of the importance of competitor analysis in the new market entry decision.

Proposition 2a: CFA usage rates are higher in "prospector" companies than in companies employing other competitive strategies.

Proposition 2b: CFA's perceived helpfulness is greater in "prospector" companies than in 
companies employing other competitive strategies.

Company size. Company size is expected to be positively related to CFA adoption. This expectation derives from the ability of larger firms to reap the benefits of lower CFA costs per sale and per employee, as well as the well-documented finding that size is positively related to greater accounting sophistication (Bruns and Waterhouse, 1975; Merchant, 1981). A further factor supporting this expected relationship stems from the earlier discussion of how employee knowledge can be a significant source of competitor information (Ghoshal and Westney, 1991; Ward, 1992). As the depth of this information source is a function of company size (more company employees signifies a greater font of competitor information), it is expected that larger firms will have a greater capacity to generate CFA information. Large firm's greater capacity to generate quality CFA data also is expected to positively impact on CFA's perceived helpfulness.

Proposition 3a: CFA usage rates are higher in larger companies.

Proposition 3b: CFA’s perceived helpfulness is greater in larger companies.

Industry. Jones (1988) sees a greater role for CFA in high technology and highly competitive industries. Foster and Gupta's (1994) study concerned with the use of accounting information in marketing decision-making also attaches significance to the role played by industry factors. The potential for industry to be a significant factor affecting CFA's usage and perceived helpfulness motivates propositions $4 \mathrm{a}$ and $4 \mathrm{~b}$.

Proposition 4a: There is significant cross-industry variation in CFA usage rates.

Proposition 4b: There is significant cross-industry variation in CFA's perceived helpfulness.

\section{METHOD AND VARIABLE MEASUREMENT}

\section{Sampling procedures}

A mailed questionnaire survey was employed. The sample was drawn from the Deloitte Touche Tohmatsu (1994) listing of New Zealand's 230 largest companies: 200 public and private companies (measured by sales), and 30 financial institutions (measured by assets). Thirteen companies where no financial accounts could be obtained or no published contact address was found were deleted from the sample, providing a final sample size of 217 companies.

Questionnaires together with a cover letter, a pre-paid return envelope and a glossary defining each of the CFA terms, together with references to the literature were mailed to the Chief Accountant in each company sampled. Two mailings resulted in 124 responses. Of these, 12 indicated an unwillingness to participate in the study (the most widely-cited reason being company policy). The 112 completed questionnaires represent a usable response rate of $51 \%$.

Two investigations for non-response bias were undertaken. Firstly, ten of the non-respondents were contacted by phone. Four non-respondents indicated the most widely-cited "too busy" or "not enough time" reasons for their non-response. One non-respondent cited "lack of interest because the practices referred to in the questionnaire are irrelevant to my organization". This gives cause for some concern, as other non-respondents may have had a similar view. The second test of non-response bias involved comparing data provided by "first mailing" respondents with data provided by "second mailing" respondents. None of the variables under investigation reveal any statistically significant association with the timing of the returns of 
completed questionnaires. While this suggests non-response bias is not a significant threat to the study's validity, the potential of the collected data being biased towards the views of accountants who are positively disposed to CFA (more likely to respond), rather than those negatively disposed towards CFA (less likely to respond), should be borne in mind.

\section{Variable measurement}

CFA Usage. Following the question, "To what extent does your organization use the following practices?", the five CFA practices were listed. Next to each one, a Likert scale ranging from "1" (not at all), to "7" (to a great extent) was provided. To aid interpretation of CFA terminology, a glossary outlining the CFA definitions presented earlier was enclosed in the mailing.

Perceived helpfulness of CFA. Similar to the format employed to measure CFA usage, following the question, "To what extent do you consider the following practices could be helpful to your organization?", the five CFA practices and the same seven point Likert scales were provided.

Strategic mission. Strategic mission was measured using Govindarajan and Gupta's (1985) measure. This measure asks respondents to record the percentage of their business unit's sales that relate most closely to four specific strategies reflective of the trade-off between market share and short-term profitability objectives. Govindarajan and Gupta referred to these four strategic mission archetypes as "build", "hold", "harvest" and "divest". These four strategic archetypes were operationalised in the measure in the following manner. The build strategy was operationalised as "Increase sales and market share, be willing to accept low returns on investment in the short-to-medium term if necessary". The hold strategy was operationalised as "Maintain market share and obtain a reasonable return on investment". The harvest strategy was operationalised as "Maximise profitability and cash flow in the short-to-medium term, be willing to sacrifice market share if necessary". The divest strategy was operationalised as "Prepare for sale or liquidation". In addition, respondents could indicate "none of the above". No respondent selected this final option. From the data collected, Govindarajan and Gupta generated a continuous variable by multiplying the percentage of sales associated with the build strategy by " +1 ", multiplying the sales percentage recorded for the hold strategy by "0", multiplying the sales percentage recorded for the harvest strategy by "-1", multiplying the sales percentage recorded for the divest strategy by "-2", and then summing the four products. In the current study, this variable had a mean of -0.12 and a distribution of values across the full range of +1 to -2 (one company recorded $100 \%$ in connection with "divest", i.e., a score of -2).

Competitive strategy. The "prospector/defender" measure derived from Miles and Snow's (1978) strategic typology was employed. This measure has been subjected to considerable psychometric assessment (Snow and Hrebiniak, 1980; Hambrick, 1983; Shortell and Zajac, 1990). Respondents were presented with a brief description of a "defender", "prospector", "analyser" and "reactor" firm and asked to select which description best represented their organization. Twenty one (19\%) respondents identified their companies as "defenders", 44 (41\%) as "prospectors", 33 (31\%) as "reactors", and 10 (9\%) as "analysers" (four respondents failed to complete this question).

Size. Company size was measured using the Deloitte Touche Tohmatsu (1994) measure of assets. This measure excludes goodwill and identifiable intangibles such as patents, trademarks, mastheads, set up and exploration costs.

Industry. Each respondent's company was identified with one of the 16 industries referred to in 
the Deloitte Touche Tohmatsu (1994) industrial classification. The industries represented in the sample are: Oil, gas, minerals and electricity (23 companies), Primary producers (14 companies), Manufacturing (15 companies), Insurance (10 companies), Processed food \& Beverage (8 companies) and Retail, wholesale and distribution (8 companies). Ten of the industrial categories were represented by five or less companies. These have been collapsed as one miscellaneous category for the purposes of the statistical analysis reported below.

\section{RESULTS}

Table 1 presents descriptive statistics for the five CFA usage rate variables. The practices are presented in descending order of usage, with means ranging from 4.95 (competitive position monitoring) to 3.41 (strategic costing). For each practice appraised, actual scores ranged across the full theoretical range. Using the paired $t$-test, each practice was found to be used statistically significantly more than the next highest ranking practice. ${ }^{3}$

Insert Table 1 about here

Table 2 presents descriptive statistics concerned with the perceived helpfulness of each of the five CFA practices. Mean scores ranged from 5.69 (competitive position monitoring) to 4.86 (strategic costing). This signifies that mean scores of all five variables were above the mid-point of the range. Again, values across the entire theoretical range were observed for each CFA practice. With the exception of a reversal of the competitor appraisal based on published financial statements and competitor cost assessment rankings, the rankings in Tables 1 and 2 were the same.

Insert Table 2 about here

Table 3 presents Pearson correlations for usage rates of the five CFA practices. The statistically significant positive correlations ( $p<0.01$ for all combinations) signify that a company with a relatively high usage of one CFA practice was likely also to use the other practices. Table 4 presents Pearson correlations for perceived helpfulness of the five CFA practices. The perceived helpfulness of the five CFA variables were also highly intercorrelated ( $p<0.01$ for all combinations). ${ }^{4}$

Insert Tables 3 and 4 about here

To test the propositions posited in the study, the data for each of the five CFA usage rate variables and each of the five perceived CFA helpfulness variables were separately fitted to the following equation:

$Y=b_{1}+b_{2}$ MISSION $+b_{3}$ COMPSTRAT $+b_{4}$ SIZE $+b_{5}$ OIL $+b_{6}$ PRIME $+b_{7}$ MANU $+b_{8} F O O D+$ $b_{8} R E T A I L+b_{9} I N S U R E$

where: $\mathrm{Y}=\mathrm{CFA}$ usage rate, or perceived CFA helpfulness;

MISSION = strategic mission;

COMPSTRAT = competitive strategy; dummy variable set equal to one (1) if prospector, otherwise zero (0); 
SIZE = \$ value of assets;

$O I L=$ oil industry; dummy variable set equal to one (1) if company is in oil, gas, minerals and electricity industry, otherwise zero (0);

PRIME = primary producer industry; dummy variable set equal to one (1) if company is in primary producer industry, otherwise zero (0);

$M A N U$ = manufacturing industry; dummy variable set equal to one (1) if company is in manufacturing industry, otherwise zero (0);

$F O O D=$ processed food \& beverage industry; dummy variable set equal to one (1) if company is in processed food \& beverage industry, otherwise zero (0);

RETAIL = retail, wholesale and distribution industry; dummy variable set equal to one (1) if company is in retail, wholesale and distribution industry, otherwise zero (0);

INSURE = insurance industry; dummy variable set equal to one (1) if company is in insurance industry, otherwise zero (0).

Table 5 presents the results of the regression analyses where usage of the five CFA practices are the dependent variables, and Table 6 presents the regression results where perceptions of the helpfulness of the five CFA practices are the dependent variables. The final columns of the two tables present the range of variable inflation factors (VIF) observed in the regression formulations. The relatively low VIFs signify that multi-collinearity did not represent a significant threat to the stability of the estimated parameters. ${ }^{5}$

Insert Tables 5 and 6 about here

Recall that proposition 1a posited a positive relationship between companies pursuing a build strategic mission and CFA usage, and proposition 1b posited a positive relationship between companies pursuing a build strategic mission and CFA's perceived helpfulness. Table 5 provides some support for proposition 1a as the coefficient for strategic mission was positive and statistically significant in connection with strategic costing $(p<0.1)$ and strategic pricing $(p$ $<0.05$ ). Stronger support for proposition $1 \mathrm{~b}$ is apparent from Table 6 as the coefficient for strategic mission was positive and statistically significant in connection with competitor cost assessment $(p<0.1)$, competitive position monitoring $(p<0.1)$, strategic costing $(p<0.01)$ and strategic pricing $(p<0.01){ }^{6}$

Proposition 2a posited a positive relationship between companies pursuing a "prospector" competitive strategy and CFA usage, and proposition $2 \mathrm{~b}$ posited a positive relationship between companies pursuing a "prospector" competitive strategy and CFA's perceived helpfulness. Support for proposition 2a is provided in Table 5 as the coefficient for competitive strategy was positive and statistically significant in connection with competitor cost assessment $(p<0.1)$, competitive position monitoring $(p<0.01)$ and competitor appraisal based on published financial statements $(p<0.05)$. Support for proposition $2 \mathrm{~b}$ is apparent from Table 6 as the coefficient for competitive strategy was positive and statistically significant in connection with competitor cost assessment $(p<0.1)$, competitive position monitoring $(p<0.05)$ and competitor appraisal based on published financial statements $(p<0.05)$.

Strong support was found for propositions 3a and 3b which posited a positive relationship between company size and CFA usage and CFA's perceived helpfulness. Size was found to play a statistically significant predictive role in nine of the ten regression equations formulated. From Table 5 it can be seen that size was statistically significantly positively related to the use of competitor cost assessment ( $p<0.05)$, competitive position monitoring $(p<0.1)$, competitor 
appraisal based on published financial statements $(p<0.05)$ and strategic costing $(p<0.05)$. From Table 6 it can be seen that size was statistically significantly positively related to the perceived helpfulness of competitor cost assessment $(p<0.05)$, competitive position monitoring $(p<0.05)$, competitor appraisal based on published financial statements $(p<0.01)$, strategic costing $(p<0.05)$ and strategic pricing $(p<0.05)$.

Negligible support was provided for propositions 4a and 4b which concern a relationship between industry and CFA use and CFA's perceived helpfulness. From Table 5 it can be seen that of the 30 relationships examined between industry and CFA usage, only one revealed a statistically significant association (the oil, gas, mineral and electricity industry was found to be significantly positively related to competitor cost assessment use, $p<0.05$ ). From Table 6 it can be seen that of the 30 relationships examined between industry and CFA's perceived helpfulness, only four revealed statistically significant associations. A significant positive relationship was found between the oil, gas, mineral and electricity industry and perceived helpfulness of competitor cost assessment $(p<0.05)$ and competitive position monitoring $(p<$ 0.1 ). A significant positive relationship was also found between the processed food and beverage industry and perceived helpfulness of competitor cost assessment $(p<0.1)$ and competitive position monitoring $(p<0.05){ }^{7}$

\section{SUMMARY AND CONCLUSIONS}

Three main findings can be distilled from this study. First, given the limited research of CFA in the management accounting literature, CFA usage has been found to be higher than what might have been reasonably anticipated. For three of the five CFA practices appraised, the mean usage was above the mid-point of a scale ranging from "not at all" to "to a great extent". There would, however, appear to be a potential for still greater use of these practices. This observation stems from the finding that the mean scores for the perceived helpfulness of all five practices surpassed the mid-point of the measurement scale. These relatively high mean scores for perceived helpfulness would also appear to provide some corroborative evidence for Ghoshal and Westney's (1991) reported gap between what is needed and what is supplied by competitor analysis systems.

A second finding relates to the relative use and perceived helpfulness of each CFA practice appraised. Competitive position monitoring has been found to be the most widely-used CFA practice and is also perceived to be of the greatest help. The definition of competitive position monitoring provided in the survey questionnaire's glossary included a reference to monitoring competitor sales and market share. As this type of information is widely available in many industries, one might have reasonably expected a relatively high ranking to be accorded to competitive position monitoring. Competitor cost assessment and strategic costing rank lowest in terms of usage and below the mid-point of the measurement scale. These observations are noteworthy as, relative to the other CFA practices, there appears to be more discussion of competitor cost assessment and strategic costing in the accounting literature.

The third finding relates to the study's contingency framework and the significant relationships found to exist between CFA and competitive strategy, strategic mission and company size. Extending prior work concerned with the relationship between accounting system design and competitive strategy archetypes (Simons, 1987; Abernethy and Guthrie, 1994), evidence uncovered here suggests that, relative to other firms, prospector firms make greater use of, and perceive greater helpfulness in, CFA practices. The results also provide an extension to Govindarajan and Gupta's (1985) work which found greater reliance on long-run performance to be more appropriate in "build" firms than in "harvest" firms. In this study it has been found 
that firms pursuing a "build" strategic mission have a greater propensity to use strategic pricing and strategic costing and perceive greater helpfulness in four of the five CFA practices appraised. Finally, extending prior work suggesting a positive relationship between company size and accounting system sophistication (e.g., Bruns and Waterhouse, 1975; Merchant, 1981), strong support has been provided for the view that size is positively related to greater use of, and greater perceived helpfulness in, CFA.

Little evidence of any systematic relationship between industry type and CFA has been found. Further work in this area might benefit from measuring any underlying constructs giving rise to an anticipated industry effect. This approach would circumvent two problems: the problem of the generic and under-defined nature of industrial classification schemes (i.e., classification based on product type might result in a breadth of production technologies, governance and capital structures, market types and other key constructs associated with a particular industrial category), and the problem arising when a firm classified in one industrial group exhibits key characteristics that are atypical of its group. Instead of attempting to relate CFA to industry, a more productive research design might involve focusing on specific variables (which might, albeit, display some relationship to industry classifications), such as type or degree of competition (see Khandwalla, 1972), technology of production, etc.

The study's findings should be interpreted in light of several limitations. In addition to generally acknowledged limitations of survey research, a significant problem revolves around defining and operationalising the CFA constructs that lie at the heart of the study. The five CFA practices considered were drawn from the literature. While this supports their credibility as accounting practices worthy of consideration, it does not preclude the possibility of overlapping practices. While due consideration was given to this problem in the course of generating the five CFA practices, it is an issue that is bound to persist in any attempt to itemise management accounting practices. The constructs were operationalised using, wherever possible, terminology and definitions that have been most widely-applied in the literature. Definitions of the terms used in the questionnaire were provided to managers participating in the study. Others, however, may have chosen to define the terms slightly differently. In connection with these problems of definition and demarcation, it should be recognised that CFA has received little attention in professional and tertiary accounting education. Standardisation of terminology used in connection with any CFA practices employed can therefore be expected to be minimal. In fact where CFA is employed, it may well be described in terms that are fairly company specific. While attention should be drawn to these limitations, in a study concerned with socially underdefined constructs, there is little that the researcher can do to counter such problems.

A potentially fruitful research initiative that builds on the current study could employ a case study design. Close involvement in one or more organizations may be the most appropriate means to further our understanding of the variety of forms that CFA can assume. Amongst the many insights that might stem from such a research initiative, we could anticipate the emergence of more sharply-defined CFA variable measures, a more complete appreciation of organisational factors affecting the adoption of CFA as well as an improved understanding of the different uses that may be made of CFA. An alternative research initiative could focus on the performance and competitiveness effects of CFA, as these effects may be seen as the acid test of CFA's efficacy. 
Table 1. Descriptive statistics for the CFA usage rate variables

\begin{tabular}{|c|c|c|c|c|c|c|c|}
\hline \multirow[b]{2}{*}{ Variable } & \multirow[b]{2}{*}{ Mean } & \multirow[b]{2}{*}{ S.D. } & \multicolumn{2}{|c|}{$\begin{array}{l}\text { Theoretical } \\
\text { range }\end{array}$} & \multicolumn{2}{|c|}{ Actual range } & \multirow[b]{2}{*}{$n$} \\
\hline & & & Min. & Max. & Min. & Max. & \\
\hline $\begin{array}{l}\text { Competitive } \\
\text { monitoring }\end{array}$ & 4.95 & 1.66 & 1 & 7 & 1 & 7 & 109 \\
\hline Strategic pricing & 4.63 & 1.70 & 1 & 7 & 1 & 7 & 100 \\
\hline $\begin{array}{l}\text { Competitor appraisal based } \\
\text { on } \\
\text { published } \\
\text { statements }\end{array}$ & 4.17 & 1.79 & 1 & 7 & 1 & 7 & 109 \\
\hline Competitor cost assessment & 3.91 & 1.83 & 1 & 7 & 1 & 7 & 108 \\
\hline Strategic costing & 3.41 & 1.78 & 1 & 7 & 1 & 7 & 98 \\
\hline
\end{tabular}

Table 2. Descriptive statistics for the perceived CFA helpfulness variables

\begin{tabular}{|c|c|c|c|c|c|c|c|}
\hline \multirow[b]{2}{*}{ Variable } & \multirow[b]{2}{*}{ Mean } & \multirow[b]{2}{*}{ S.D. } & \multicolumn{2}{|c|}{$\begin{array}{c}\text { Theoretical } \\
\text { range }\end{array}$} & \multicolumn{2}{|c|}{ Actual range } & \multirow[b]{2}{*}{$n$} \\
\hline & & & Min. & Max. & Min. & Max. & \\
\hline $\begin{array}{l}\text { Competitive } \\
\text { monitoring }\end{array}$ & 5.69 & 1.31 & 1 & 7 & 1 & 7 & 104 \\
\hline Strategic pricing & 5.32 & 1.58 & 1 & 7 & 1 & 7 & 95 \\
\hline Competitor cost assessment & 5.16 & 1.58 & 1 & 7 & 1 & 7 & 104 \\
\hline $\begin{array}{l}\text { Competitor appraisal based } \\
\text { on } \\
\text { published } \\
\text { statements }\end{array}$ & 5.05 & 1.59 & 1 & 7 & 1 & 7 & 104 \\
\hline Strategic costing & 4.86 & 1.84 & 1 & 7 & 1 & 7 & 96 \\
\hline
\end{tabular}


TABLE 3. Matrix of Pearson product moment correlation coefficients for the five CFA usage variables

\begin{tabular}{|c|c|c|c|}
\hline $\begin{array}{l}\text { Competitor } \\
\text { cost } \\
\text { assessment }\end{array}$ & $\begin{array}{c}\text { Competitive } \\
\text { position } \\
\text { monitoring }\end{array}$ & $\begin{array}{l}\text { Competitor appraisal } \\
\text { based on published } \\
\text { financial statements }\end{array}$ & \\
\hline
\end{tabular}

Competitive position

monitoring

0.56

Competitor appraisal

based on published

financial statements

Strategic

Costing

Strategic

Pricing

0.65

0.43

0.35
0.63

0.29

0.32

0.41

0.31

0.46

All correlation coefficients are statistically significant $(p<0.01)$.

TABLE 4. Matrix of Pearson product moment correlation coefficients for the five CFA perceived helpfulness variables

Competitor Competitive Competitor appraisal

cost position based on published Strategic

assessment monitoring financial statements costing

Competitive position

monitoring

0.71

Competitor appraisal

based on published

$0.73 \quad 0.66$

financial statements

$\begin{array}{llll}\text { Strategic } & 0.45 & 0.28 & 0.37\end{array}$

Costing

Strategic

0.44

0.45

0.33

0.66

Pricing

All correlation coefficients are statistically significant $(p<0.01)$. 
Table 5. CFA adoption rates regression analysis ${ }^{\mathrm{a}}$

\begin{tabular}{|c|c|c|c|c|c|c|}
\hline & $\begin{array}{l}\text { Competitor } \\
\text { cost } \\
\text { assessment }\end{array}$ & $\begin{array}{c}\text { Competitive } \\
\text { position } \\
\text { monitoring }\end{array}$ & $\begin{array}{c}\text { Competitor } \\
\text { appraisal } \\
\text { based on } \\
\text { published } \\
\text { financial } \\
\text { statements }\end{array}$ & $\begin{array}{l}\text { Strategic } \\
\text { costing }\end{array}$ & $\begin{array}{c}\text { Strategi } \\
\text { c } \\
\text { pricing }\end{array}$ & $\begin{array}{c}\text { Variable } \\
\text { inflation } \\
\text { factor } \\
\text { range }\end{array}$ \\
\hline Constant & $\begin{array}{c}3.02 * * * \\
(8.03)\end{array}$ & $\begin{array}{c}4.26 * * * \\
(12.97)\end{array}$ & $\begin{array}{c}3.56 * * * \\
(9.58)\end{array}$ & $\begin{array}{c}3.10^{* * * *} \\
(7.22)\end{array}$ & $\begin{array}{c}4.29 * * \\
* \\
(11.07)\end{array}$ & \\
\hline $\begin{array}{l}\text { Strategic } \\
\text { Mission }\end{array}$ & $\begin{array}{l}-0.01 \\
(-0.11)\end{array}$ & $\begin{array}{c}0.09 \\
(0.92)\end{array}$ & $\begin{array}{c}0.01 \\
(0.07)\end{array}$ & $\begin{array}{l}0.14^{*} \\
(1.36)\end{array}$ & $\begin{array}{c}0.18 * * \\
(1.76)\end{array}$ & $1.07-1.13$ \\
\hline $\begin{array}{l}\text { Competitive } \\
\text { Strategy }\end{array}$ & $\begin{array}{l}0.17^{*} \\
(1.62)\end{array}$ & $\begin{array}{c}0.37 * * * \\
(3.75)\end{array}$ & $\begin{array}{l}0.22^{* *} \\
(2.19)\end{array}$ & $\begin{array}{c}0.11 \\
(1.02)\end{array}$ & $\begin{array}{c}0.08 \\
(0.71)\end{array}$ & $1.07-1.11$ \\
\hline Size & $\begin{array}{l}0.21^{* *} \\
(2.08)\end{array}$ & $\begin{array}{l}0.13^{*} \\
(1.36)\end{array}$ & $\begin{array}{l}0.22 * * \\
(2.17)\end{array}$ & $\begin{array}{l}0.21^{* *} \\
(1.85)\end{array}$ & $\begin{array}{c}0.13 \\
(1.15)\end{array}$ & $1.15-1.27$ \\
\hline $\begin{array}{l}\text { Oil, gas, mineral \& } \\
\text { electricity industry }\end{array}$ & $\begin{array}{l}0.25^{* *} \\
(2.20)\end{array}$ & $\begin{array}{c}0.10 \\
(0.94)\end{array}$ & $\begin{array}{c}0.09 \\
(0.87)\end{array}$ & $\begin{array}{c}0.10 \\
(0.78)\end{array}$ & $\begin{array}{c}-0.05 \\
(-0.39)\end{array}$ & $1.38-1.52$ \\
\hline $\begin{array}{l}\text { Primary producer } \\
\text { industry }\end{array}$ & $\begin{array}{c}0.17 \\
(1.56)\end{array}$ & $\begin{array}{l}-0.03 \\
(-0.27)\end{array}$ & $\begin{array}{c}0.11 \\
(1.06)\end{array}$ & $\begin{array}{l}-0.04 \\
(-0.35)\end{array}$ & $\begin{array}{c}0.01 \\
(0.06)\end{array}$ & $1.28-1.37$ \\
\hline $\begin{array}{l}\text { Manufacturing } \\
\text { industry }\end{array}$ & $\begin{array}{c}0.00 \\
(0.03)\end{array}$ & $\begin{array}{l}-0.03 \\
(-0.30)\end{array}$ & $\begin{array}{l}-0.02 \\
(-0.18)\end{array}$ & $\begin{array}{c}0.00 \\
(0.03)\end{array}$ & $\begin{array}{c}0.07 \\
(0.61)\end{array}$ & $1.32-1.45$ \\
\hline $\begin{array}{l}\text { Processed food } \\
\text { \& beverage } \\
\text { industry }\end{array}$ & $\begin{array}{c}0.12 \\
(1.17)\end{array}$ & $\begin{array}{c}0.13 \\
(1.30)\end{array}$ & $\begin{array}{l}-0.01 \\
(-0.08)\end{array}$ & $\begin{array}{c}0.05 \\
(0.47)\end{array}$ & $\begin{array}{c}0.18 \\
(1.64)\end{array}$ & $1.18-1.26$ \\
\hline $\begin{array}{l}\text { Retail, wholesale \& } \\
\text { Distribution } \\
\text { industry }\end{array}$ & $\begin{array}{c}0.07 \\
(0.72)\end{array}$ & $\begin{array}{c}0.02 \\
(0.17)\end{array}$ & $\begin{array}{c}0.02 \\
(0.18)\end{array}$ & $\begin{array}{l}-0.05 \\
(-0.40)\end{array}$ & $\begin{array}{c}0.15 \\
(1.37)\end{array}$ & $1.19-1.24$ \\
\hline $\begin{array}{l}\text { Insurance } \\
\text { Industry }\end{array}$ & $\begin{array}{c}0.07 \\
(0.65)\end{array}$ & $\begin{array}{c}0.03 \\
(0.35)\end{array}$ & $\begin{array}{c}-0.05 \\
(-0.47)\end{array}$ & $\begin{array}{c}0.02 \\
(0.18)\end{array}$ & $\begin{array}{c}0.03 \\
(0.31)\end{array}$ & $1.21-1.23$ \\
\hline $\begin{array}{c}\text { Adjusted } R^{2} \\
F \\
p \\
n\end{array}$ & $\begin{array}{l}0.03 \\
1.42 \\
0.19 \\
108\end{array}$ & $\begin{array}{l}0.12 \\
2.63 \\
0.00 \\
109\end{array}$ & $\begin{array}{l}0.04 \\
1.44 \\
0.18 \\
109\end{array}$ & $\begin{array}{c}0.00 \\
0.95 \\
0.48 \\
98\end{array}$ & $\begin{array}{l}0.03 \\
1.29 \\
0.25 \\
100\end{array}$ & \\
\hline
\end{tabular}


${ }^{a}$ Each cell reports the standardized regression coefficient followed by $t$-statistic in parentheses. For competitive strategy, strategic mission and size, one-tailed tests of statistical significance were employed. For the industry variables, two-tailed tests of statistical significance were employed.

b Due to some missing values for the dependent variables, the variable inflation factors (VIFs) exhibit a small degree of variation across the five regression equations formulated. The range of VIFs observed are reported.

$* p<0.10$

$* * p<0.05$

$* * * p<0.01$ 
Table 6. Perceived CFA helpfulness regression analysis ${ }^{\mathrm{a}}$

\begin{tabular}{|c|c|c|c|c|c|c|}
\hline & $\begin{array}{l}\text { Competitor } \\
\text { cost } \\
\text { assessment }\end{array}$ & $\begin{array}{l}\text { Competitive } \\
\text { position } \\
\text { monitoring }\end{array}$ & $\begin{array}{c}\text { Competitor } \\
\text { appraisal } \\
\text { based on } \\
\text { published } \\
\text { financial } \\
\text { statements }\end{array}$ & $\begin{array}{l}\text { Strategic } \\
\text { costing }\end{array}$ & $\begin{array}{c}\text { Strategi } \\
\text { c } \\
\text { pricing }\end{array}$ & $\begin{array}{c}\text { Variable } \\
\text { inflation } \\
\text { factor } \\
\text { range }\end{array}$ \\
\hline Constant & $\begin{array}{c}4.44 * * * \\
(13.74)\end{array}$ & $\begin{array}{l}5.07 * * * \\
(19.23)\end{array}$ & $\begin{array}{l}4.59 * * * \\
(13.60)\end{array}$ & $\begin{array}{c}4.55 * * * \\
(11.12)\end{array}$ & $\begin{array}{c}5.02^{* *} \\
* \\
(14.68)\end{array}$ & \\
\hline $\begin{array}{l}\text { Strategic } \\
\text { Mission }\end{array}$ & $\begin{array}{l}0.13^{*} \\
(1.30)\end{array}$ & $\begin{array}{l}0.13^{*} \\
(1.36)\end{array}$ & $\begin{array}{c}0.10 \\
(0.95)\end{array}$ & $\begin{array}{c}0.26 * * * \\
(2.55)\end{array}$ & $\begin{array}{c}0.26^{* * *} \\
* \\
(2.53)\end{array}$ & $1.07-1.08$ \\
\hline $\begin{array}{l}\text { Competitive } \\
\text { Strategy }\end{array}$ & $\begin{array}{l}0.15^{*} \\
(1.46)\end{array}$ & $\begin{array}{l}0.18^{* *} \\
(1.71)\end{array}$ & $\begin{array}{l}0.22^{* *} \\
(2.07)\end{array}$ & $\begin{array}{c}0.07 \\
(0.66)\end{array}$ & $\begin{array}{c}0.03 \\
(0.30)\end{array}$ & $1.08-1.10$ \\
\hline Size & $\begin{array}{l}0.19 * * \\
(1.87)\end{array}$ & $\begin{array}{l}0.18 * * \\
(1.80)\end{array}$ & $\begin{array}{l}0.15^{*} \\
(1.46)\end{array}$ & $\begin{array}{l}0.21^{* *} \\
(1.94)\end{array}$ & $\begin{array}{c}0.22 * * \\
(2.01)\end{array}$ & $1.15-1.18$ \\
\hline $\begin{array}{l}\text { Oil, gas, mineral \& } \\
\text { electricity industry }\end{array}$ & $\begin{array}{l}0.26^{* *} \\
(2.32)\end{array}$ & $\begin{array}{l}0.21^{*} \\
(1.89)\end{array}$ & $\begin{array}{c}0.16 \\
(1.37)\end{array}$ & $\begin{array}{c}0.16 \\
(1.31)\end{array}$ & $\begin{array}{c}0.11 \\
(0.94)\end{array}$ & $1.33-1.45$ \\
\hline $\begin{array}{l}\text { Primary producer } \\
\text { industry }\end{array}$ & $\begin{array}{c}0.12 \\
(1.09)\end{array}$ & $\begin{array}{c}0.05 \\
(0.43)\end{array}$ & $\begin{array}{c}0.03 \\
(0.23)\end{array}$ & $\begin{array}{c}0.04 \\
(0.40)\end{array}$ & $\begin{array}{c}-0.02 \\
(-0.19)\end{array}$ & $1.24-1.32$ \\
\hline $\begin{array}{l}\text { Manufacturing } \\
\text { industry }\end{array}$ & $\begin{array}{c}0.04 \\
(0.41)\end{array}$ & $\begin{array}{c}0.10 \\
(0.95)\end{array}$ & $\begin{array}{l}-0.05 \\
(-0.43)\end{array}$ & $\begin{array}{l}-0.10 \\
(-0.90)\end{array}$ & $\begin{array}{c}-0.03 \\
(-0.27)\end{array}$ & $1.27-1.40$ \\
\hline $\begin{array}{l}\text { Processed food } \\
\text { \& beverage } \\
\text { industry }\end{array}$ & $\begin{array}{l}0.19 * \\
(1.80)\end{array}$ & $\begin{array}{l}0.22 * * \\
(2.15)\end{array}$ & $\begin{array}{c}0.05 \\
(0.52)\end{array}$ & $\begin{array}{c}0.18 \\
(1.68)\end{array}$ & $\begin{array}{c}0.18 \\
(1.65)\end{array}$ & $1.18-1.26$ \\
\hline $\begin{array}{l}\text { Retail, wholesale \& } \\
\text { Distribution } \\
\text { industry }\end{array}$ & $\begin{array}{c}0.01 \\
(0.06)\end{array}$ & $\begin{array}{c}0.11 \\
(1.08)\end{array}$ & $\begin{array}{l}-0.08 \\
(-0.74)\end{array}$ & $\begin{array}{l}-0.05 \\
(-0.45)\end{array}$ & $\begin{array}{c}0.01 \\
(0.06)\end{array}$ & $1.18-1.26$ \\
\hline $\begin{array}{l}\text { Insurance } \\
\text { Industry }\end{array}$ & $\begin{array}{c}0.14 \\
(1.37)\end{array}$ & $\begin{array}{c}0.13 \\
(1.24)\end{array}$ & $\begin{array}{c}0.04 \\
(0.38)\end{array}$ & $\begin{array}{c}0.60 \\
(0.54)\end{array}$ & $\begin{array}{c}0.15 \\
(1.35)\end{array}$ & $1.19-1.27$ \\
\hline $\begin{array}{c}\text { Adjusted } R^{2} \\
F \\
p \\
n \\
\end{array}$ & $\begin{array}{l}0.06 \\
1.70 \\
0.09 \\
104\end{array}$ & $\begin{array}{l}0.07 \\
1.79 \\
0.08 \\
104\end{array}$ & $\begin{array}{l}0.03 \\
1.29 \\
0.25 \\
104\end{array}$ & $\begin{array}{c}0.10 \\
2.11 \\
0.04 \\
96\end{array}$ & $\begin{array}{c}0.07 \\
1.74 \\
0.09 \\
95\end{array}$ & \\
\hline
\end{tabular}


${ }^{a}$ Each cell reports the standardized regression coefficient followed by $t$-statistic in parentheses. For competitive strategy, strategic mission and size, one-tailed tests of statistical significance were employed. For the industry variables, two-tailed tests of statistical significance were employed.

b Due to some missing values for the dependent variables, the variable inflation factors (VIFs) exhibit a small degree of variation across the five regression equations formulated. The range of VIFs observed are reported.

$* p<0.10$

$* * p<0.05$

$* * * p<0.01$ 


\section{BIBLIOGRAPHY}

Abernethy, M. A. \& Guthrie, C. H. (1994). An Empirical Assessment of the "Fit" between Strategy and Management Information System Design. Accounting and Finance, 49-66.

Bromwich, M. (1990). The Case for Strategic Management Accounting: The Role of Accounting Information for Strategy in Competitive Markets. Accounting, Organizations and Society, 27-46.

Bruns, W. J., Jr., \& Waterhouse, J. H. (1975). Budgetary Control and Organization Structure. Journal of Accounting Research, Autumn, 177-203.

Chapman, C. S. (1997). Reflections on a Contingent View of Accounting. Accounting, Organizations and Society, 189-205.

Deloitte Touche Tohmatsu. (1994). The 1994 Top 200. Management, 88-108.

Dent, J. F. (1990). Strategy, Organisation and Control: Some Possibilities for Accounting Research. Accounting, Organizations and Society, 3-25.

Foster, G. \& Gupta, M. (1994). Marketing, Management and Management Accounting. Journal of Management Accounting Research, 43-77.

Ghoshal, S. \& Westney, D. E. (1991). Organizing Competitor Analysis Systems. Strategic Management Journal, 17-31.

Govindarajan, V., \& Gupta, A. K. (1985). Linking control systems to business unit strategy: impact on performance. Accounting, Organizations and Society, 51-66.

Hambrick, D. (1983). Some Tests of the Effectiveness and Functional Attributes of Miles and Snow's Strategic Types. Academy of Management Journal, 5-26.

Information Data Search. (1985). Competitor Intelligence Gathering: A Survey. Cambridge, MA: IDS.

Jones, L. (1988). Competitor Cost Analysis at Caterpillar. Management Accounting (US), October, 32-38.

Khandwalla, P. N. (1972). The Effect of Different Types of Competition on the Use of Management Controls. Journal of Accounting Research, Autumn, 275-285.

Langfield-Smith, K. (1997). Management Control Systems and Strategy: A Critical Review. Accounting, Organizations and Society, 207-232.

Merchant, K. A. (1981). The Design of the Corporate Budgeting System: Influences on Managerial Behavior and Performance. The Accounting Review, October, 813-829.

Miles, R. E. \& Snow, C. C. (1978). Organizational Strategy, Structure and Process. New York: McGraw Hill.

Moon, P., \& Bates, K. (1993). Core analysis in strategic performance appraisal. Management 
Accounting Research, 139-152.

Otley, D. T. (1980). The Contingent Theory of Management Accounting: Achievement and Prognosis. Accounting, Organizations and Society, 413-428.

Palepu, K. G., Bernard, V. L., \& Healy, P. M. (1995). Business Analysis and Valuation. Cincinatti: South-Western Publishing.

Porter, M. E. (1980). Competitive Strategy: Techniques for Analyzing Industries and Competitors. New York: Free Press.

Porter, M. E. (1985). Competitive Advantage: Creating and Sustaining Superior Performance. New York: Free Press.

Shank, J. K., \& Govindarajan, V. (1988). Making Strategy Explicit in Cost Analysis: A Case Study. Sloan Management Review, Spring, 19-29.

Shank, J. K., \& Govindarajan, V. (1991). Strategic Cost Management and the Value Chain. In Brinker, B. (Ed), Handbook of Cost Management. New York: Warren, Gorham and Lamont.

Shank, J. K., \& Govindarajan, V. (1992). Strategic Cost Management: The Value Chain Perspective. Journal of Management Accounting Research, Fall, 179-198.

Shank, J. K., \& Govindarajan, V. (1993). What "Drives" Cost? A Strategic Cost Management Perspective. Advances in Management Accounting, 27-46.

Shortell, S. \& Zajac, E. (1990). Perceptual and Archival Measures of Miles and Snow's Strategic Types: A Comprehensive Assessment of Reliability and Validity. Academy of Management Journal, 817-832.

Simmonds, K. (1981). Strategic Management Accounting. Management Accounting, 26-29.

Simmonds, K. (1982). Strategic management accounting for pricing: a case example. Accounting and Business Research, 206-214.

Simmonds, K. (1986). The accounting assessment of competitive position. European Journal of Marketing, 16-31.

Simons, R. (1987). Accounting control systems and business strategy: An empirical analysis. Accounting, Organizations and Society, 357-374.

Simons, R. (1990). The Role of Management Control Systems in Creating Competitive Advantage: New Perspectives. Accounting, Organizations and Society, 127-143.

Snow, C. C. \& Hrebiniak, L. G. (1980). Strategy, Distinctive Competence and Organizational Performance. Administrative Science Quarterly, 317-336.

Stickney, C. P. (1990). Financial Statement Analysis: A Strategic Perspective. San Diego: Harcourt Brace Jovanivich.

Ward, K. (1992). Accounting for Marketing Strategies. In Drury C. (Ed), Management 
Accounting Handbook (pp.154-172). Oxford: Butterworth-Heinemann.

Zajac, E. J. \& Bazerman, M. H. (1991). Blind Spots in Industry and Competitor Analysis: Implications of Interfirm (Mis)perceptions for Strategic Decisions. Academy of Management Review, 37-56. 
1 Information Data Search (1985) reports that in 1985, more than a third of Fortune 500 companies were spending over \$US 1 million a year on competitor analysis. Ghoshal and Westney (1991) report that the Society of Computer Intelligence professionals, a new U.S. professional forum, held its first annual meeting in 1986, and its 1988 meeting was attended by representatives from over 200 large corporations and over 40 consulting firms.

2 See Palepu et al (1995) and Stickney (1990) for further elaboration of a competitor focus in financial statement analysis.

3 Competitive position monitoring was used significantly more than strategic pricing $(p<0.05)$, strategic pricing was used more than competitor appraisal based on published financial statements $(p<0.05)$, competitor appraisal based on published financial statements was used more than competitor cost assessment $(p<0.1)$, and competitor cost assessment was used more than strategic costing $(p<0.01)$.

${ }^{4}$ These findings provide preliminary support for the propositions. As it was proposed the four contingencies under study impact on usage and also perceived helpfulness of all five CFA practices, we would expect the usage rates and also the perceived helpfulness of the five practices to be positively inter-correlated. Exploratory factor analysis of the five CFA usage rate variables yielded a one factor result (56\% total variance explained). Factor analysis of the perceived helpfulness CFA variables yielded a two factor result (61\% and $21 \%$ total variance explained), with strategic pricing and strategic costing representing the second factor. In light of the exploratory nature of the study, rather than using the factor analytic outputs in the examination of the proposed contingency relationships, it was believed greater insight derives from treating the CFA variables independently.

${ }^{5}$ Due to some missing values for the dependent variables, the VIFs exhibited a small degree of variation across each of the regression equations formulated. Across all 10 regression equations, the highest VIF (1.52) was yielded by "oil industry" where "strategic costing usage" is the dependent variable. The presence of negligible multi-collinearity was also evident from relatively low condition indices yielded by the independent variables. Where "strategic costing usage" is the dependent variable, the 10 condition indices were 1.00, 1.50, 1.59, 1.61, 1.62, 1.62, 1.68, 1.88, 2.24, 4.96 .

6 The sensitivity of these results to the way the Govindarajan and Gupta measure was calculated has been investigated by computing an alternative measure for strategic mission. Under this alternative method, " +1 ” has been recorded if the respondent reported the highest percentage of sales as associated with the "build" mission, " 0 ” is scored where "hold” ranks highest, “-1" is scored where "harvest” ranks highest and "-2" is scored where "divest” ranks highest. The ten regression equations were reformulated using this alternative measure of strategic mission. The alternative measure was significantly positively related to the use of two CFA practices (competitor position monitoring, $p<0.1$; strategic pricing, $p<0.1$ ), and perceived helpfulness of three practices (competitor position monitoring, $p<0.1$; strategic pricing, $p<0.05$; strategic costing, $p<0.05$ ). These results provided further corroborating support for propositions $1 \mathrm{a}$ and $1 \mathrm{~b}$.

${ }^{7}$ Due to the limited significance of the industry variables in the analysis, the impact of excluding them from the regression formulations was also investigated. When the industry variables were omitted, only two of the ten equations failed to achieve significance at the $10 \%$ confidence limit (i.e., where competitor cost assessment usage and strategic pricing usage were the dependent variables). The following three changes in the remaining independent variables' levels of significance were also noted in the modified regression formulations: competitive strategy was not statistically significant where competitor cost assessment usage and also perceived helpfulness were the dependent variables, and size recorded a lower level of statistical significance where competitive position monitoring helpfulness was the dependent variable $(p<0.1)$. 